\title{
Chemical Properties and Mineralogical Composition of Soils in Original site at Coal Mining Area, East Kalimantan
}

\author{
Ria Rachel Paranoan *)
}

Dept. Agroecotechnology, Fakulty of Agriculture, University of Mulawarman

Corresponding Author:: rachelria_paranoan@yahoo.co.id

\begin{abstract}
Soil minerals and chemical properties play an essential role in agricultural, especially to know the availability of soil nutrient reserve. The objective of the study was to investigate soil chemical properties and mineralogical composition of sand fraction in original area. The study was conducted in two stages. The First stage was in the field and the second stage was in the laboratory. The field study was at Original area PT. Khotai Makmur Insan Abadi, Kutai Kartanegara, East Kalimantan. Soils were sampled from each horizon of the profile. The second stage was in the Laboratory. The chemical analysis was conducted in the Soil Laboratory, Agriculture Faculty, Mulawarman University. The Mineralogical composition of fine sand fractions was conducted in Pusat penelitian tanah Bogor, with line counting method using Microscope Polaritation (MP). The results of chemical characteristics indicated that low to very low content of organic matter, soil reactions are acid throughout the horizon, very low to moderate base satration, low to moderate soil cation exchange capacity, high of Al saturation. Sand fraction composition was dominated by resistant minerals (quartz and opaque). On the other hand the easily weatherable minerals are not detected in the original area. One of the reason soil has low CEC is, because the composition of sand fraction in the soil dominated by quartz.
\end{abstract}

Keywords :Chemical Properties, Mineralogical composition, Microscope Polaritation, Quartz, Sand Fraction.

Reference to this paper should be made as follows :

Paranoan, R. R. 2019. Chemical Properties and Mineralogical Composition of Soils in Original site at Coal Mining Area, East Kalimantan. Agritropica: Journal of Agricultural Science. 2(2): 71076. Doi: https:// doi.org/10.31186/Jagritropica.2.2.71-76

\section{INTRODUCTION}

Soil chemical properties have strong association with primary minerals composition. The composition of primary minerals influences chemical properties, particularly in soil management practices (Anda et al. 2012).

Soil Minerals are important substance in soil formed, from cooling magma. According to Allen and Fanning (1983), the mineral componenets of many soils are inherited almost from the parent material.

Quartz is most abundant several varieties of silica glass (Wilding et al.
1977), one of the most resistant minerals. It is present in sand and silt fractions.

Feldspars belong to the group of Minerals, divided into orthoclase and plagioclase. The primary minerals in East Kalimantan consist of easily weatherable minerals (feldspar hornblende, plagioclase, olivine, pyroxene, amphibole volcanic glass), and resistant we a therable minerals such as quartz and opaque (Prasetyo et al. 2001; Anda et al. 2012; Pramuji and Bustaman, 2009). Primary minerals (sand fractions) are formed by physical weathering of the rocks. Primary minerals have been components of previously existing soils (Allen and 
Fanning, 1983).

The mineralogical and chemical studies have been characterized by some researches (Anda et al, 2012; Ohta et al, 1992, Anda et al, 2016); Prasetyo et al, 2001, Prasetyo and Suriadikarta, 2006); Sanchez et al (2019); Pramuji and Bastaman, 2009; Prasetyo, 2007); Portela et al (2019), however, it's still no detailed information on the soil of Kutai Kartanegara, East Kalimantan, specially original area at PT. Khotai Makmur Insan Abadi. The purpose of the current study was to determine the chemical properties and mineralogical composition of sand fractions in original area at PT. Khotai Makmur Insan Abadi, Kutai Kartanegara, East Kalimantan.

\section{MATERIALS AND METHODS}

\section{Study Area}

The major study field was selected in the PT. Khotai Maksmur Insan Abadi, Kutai Kartatenagara, Province of East Kalimantan was at original area (nursery area). The original (Nursery) area at PT. Khotai Makmur Insan Abadi, Kutai Kartanegara covering \pm 1.31 ha.

The study was conducted for 5 months from April to September 2019. Four soil sampled from each horizon of profil ( $00^{0} 14^{\prime} 02,6^{\prime \prime} \mathrm{S}-117^{0} 06^{\prime} 44,4^{\prime \prime} \mathrm{E}$ ) in original (nursery) area at PT. Khotai Makmur Insan Abadi, Kutai Kartanegara, East Kalimantan.

\section{Analytical Method}

\section{Chemical Analysis}

The $500 \mathrm{~g}$ of soil sampel from each horizon for chemical analysis. Analysis was conducted at Soil Laboratorium, Agriculture Faculty, Mulawarman University.
Data analysis consists oftekxture, $\mathrm{pH}\left(\mathrm{H}_{2} \mathrm{O}\right)$ was measured by the glass electrode methodon 1 : 2.5 soil:water, CEC ( cation exchange capacity) using 1 $\mathrm{N}$ ammonium acetate $\left(\mathrm{NH}_{4} \mathrm{OAC}\right)$ at pH 7.0 as an extractant, organic carbon (Walkley and Black Method, using spectrophotometry), Base Saturation (\%) was expressed by the percentage of sum of $\mathrm{Ca}, \mathrm{Mg}, \mathrm{K}$ and $\mathrm{Na}$ in $1 \mathrm{~N}$ ammonium acetate $\left(\mathrm{NH}_{4} \mathrm{OA}_{\mathrm{C}}\right)$ at $\mathrm{pH} 7.0$.

\section{Mineralogical analysis}

The $500 \mathrm{gr}$ of oil sample representing each horizon was taken for mineralogical of the sand fractions analysis. The soil samples were destruction with $\mathrm{H}_{2} \mathrm{O}_{2}(30 \%)$ and $\mathrm{HCL}$ (10\%). The mineralogical compositions of sand fractions of soils were analyzed at Laboratory of Mineral (BB Litbang SDLP), Bogor, using a polarizing microscope (PM).

\section{RESULTS AND DISCUSSION}

\section{Composition of The sand fraction Minerals}

Based on fine sand fractions analysis usinga polarizing microscope (PM), composition of minerals in sand fractions of soil profile from original (nursery) area at coal mining is given in Table 1. The finding provides evidence that primary mineral composition of soils dominated by resistant minerals are quartz and opaque. The composition of Quartz (84-86\%), opaque (1-4\%), Zirkon (1-3\%), weathered mineral ( 3$6 \%)$, rock fraction $(1-2 \%)$. Quartz is the most stable mineral (Rajamuddin et al.,2013). The resistant minerals have no potential reserved nutrients in the soil 
(Anda et al, 2012). On the other hand the composition of weatherable minerals such as feldspar, mineral group, ferromagnesian mineral group which is potential sources in reserved nutrients are not found.

\section{Soil Properties}

Some chemical properties of soil in original area at PT. Khotai Makmur Insan Abadi, i.e., $\mathrm{pH}\left(\mathrm{H}_{2} \mathrm{O}\right)$, texture (particle size), organic carbon, base saturation, cation exchange capacity (CEC), exchangeable cation, $\mathrm{Al}$ saturation, available $\mathrm{P}$ are shown in Table 2 and 3.

Table 1. Mineralogical composition of fine sand fractions $(50-250 \mu \mathrm{m})$

\begin{tabular}{ccccccccccccccccc}
\hline $\begin{array}{c}\text { Depth } \\
(\mathrm{cm})\end{array}$ & Op & $\mathrm{Zi}$ & Qt & Wm & Rf & Vg & Og & Bw & An & Or & Sn & An & Hb & Au & En & Total \\
\hline $0-25$ & 1 & 3 & 85 & 5 & 1 & - & - & - & - & - & - & - & - & - & - & 100 \\
$25-60$ & 4 & 1 & 86 & 4 & 1 & - & - & - & - & - & - & - & - & - & - & 100 \\
$60-90$ & 2 & 1 & 84 & 6 & - & - & - & - & - & - & - & - & - & - & - & 100 \\
$90-120$ & 3 & 2 & 85 & 3 & 2 & - & - & - & - & - & - & - & - & - & - & 100 \\
\hline$-=$
\end{tabular}

As illustrated in Table 2, the topsoil tekxture showed that the particle size class is loam, with $24.38 \%$ clay, $29.76 \%$ silt, and $45.86 \%$ sand fraction. The subsoil has clay content varying from 26.87 to $36.39 \%$, the silt fraction varying from 22.27 to $36.62 \%$ and sand fraction content varying from 26.99 to $50.86 \%$. The sub soil texture varies from clay loam to sandy clay loam. This means that the topsoil contains a lower content of clay than the subsoil.

The cation exchange capacity (CEC) of soil from the the topsoil to the subsoil content varying from low to moderate (14.48-21.64 me/100g). Cation exchange capacity is affected by soil $\mathrm{pH}$. From topsoil to subsoil the soil $\mathrm{pH}$ in $\mathrm{H}_{2} \mathrm{O}$ acid (4.64-4.57). The reason for low of CEC in both topsoil and subsoil is because the clay content in topsoil and subsoil is lower than sand content.

The organic carbon from the topsoil to the subsoil showed low ( $1.18 \%)$ to very low $(0.40-0.97 \%)$. The organic carbon content in the subsoil is always lower than in the topsoil. Organic carbon content in soil can affects another soil properties, specifically cation exchange capacity (CEC). 
Table 2.pH, CEC, Organic-Carbon, BaseSaturation, Particle Size

\begin{tabular}{|c|c|c|c|c|c|c|c|c|}
\hline \multirow[t]{3}{*}{ Horizon } & Depth & $\mathrm{pH}$ & CEC & $\begin{array}{c}\text { Organic- } \\
\text { C }\end{array}$ & $\begin{array}{c}\text { Bases } \\
\text { Saturation }\end{array}$ & \multicolumn{3}{|c|}{ Particle Size } \\
\hline & & & & & & Clay & Silt & Sand \\
\hline & $(\mathrm{cm})$ & $\mathrm{H} 2 \mathrm{O}$ & $\mathrm{me} / 100 \mathrm{~g}$ & $\%$ & $\%$ & & $\%$ & \\
\hline $\mathrm{A}$ & $0-25$ & 4.64 & 16.35 & 1.18 & 41.30 & 24.38 & 29.76 & 45.86 \\
\hline B1 & $25-60$ & 4.62 & 14.48 & 0.84 & 30.27 & 30.66 & 32.79 & 36.55 \\
\hline B2 & $60-90$ & 4.60 & 21.64 & 0.97 & 26.98 & 26.87 & 22.27 & 50.86 \\
\hline B3 & $90-120$ & 4.57 & 18.87 & 0.40 & 18.93 & 36.39 & 36.62 & 26.99 \\
\hline
\end{tabular}

Table 2 provides that base saturation in the surface horizon content moderate $(41.30 \%)$, in the subsoil base saturation varies from low to very low ( $30.27-18.93 \%$ ). Base saturation in the topsoil is higher than in the subsoil. This is similar to the result of study by Prasetyo et al (2001) who finds that the base saturation of top soil is slightlyhigher than subsoil.
As Table 2 present the $\mathrm{pH}$ of both soils, topsoil and subsoil, was acidic $\left(\mathrm{H}_{2} \mathrm{O}-\mathrm{pH} 4.57\right.$ - 4.64). High level of measurable acidity are connected with the low base content in soil (Miller, 1983). Soil reaction are highly related to base saturation, itinfluences the base saturation, soil with low $\mathrm{pH}$ generally has low base saturation, the higher the Soil $\mathrm{pH}$ leads to the higher base saturation ( Hardjowigeno, 2003).

Table 3. Al Saturation, Available P, Cations Exchange

\begin{tabular}{|c|c|c|c|c|c|c|c|c|c|}
\hline \multirow[t]{3}{*}{ Horizon } & \multirow{3}{*}{$\begin{array}{l}\text { Depth } \\
(\mathrm{cm})\end{array}$} & \multirow{3}{*}{$\begin{array}{c}\mathrm{Al} \\
\text { Saturation } \\
\%\end{array}$} & \multirow{3}{*}{$\begin{array}{l}\text { Av. P } \\
\text { Bray } \\
\text { ppm }\end{array}$} & \multicolumn{6}{|c|}{ Exchangeable Cation (pH 7) } \\
\hline & & & & $\mathrm{Ca}++$ & $\mathrm{Mg}++$ & $\mathrm{K}+$ & $\mathrm{Na}+$ & $\mathrm{Al+++}$ & $\mathrm{H}^{+}$ \\
\hline & & & & \multicolumn{5}{|c|}{$\mathrm{meq} / 100 \mathrm{~g}$} & $\%$ \\
\hline A & $0-25$ & 30.57 & 19.49 & 4.01 & 2.06 & 0.49 & 0.2 & 5.00 & 4.60 \\
\hline B1 & $25-60$ & 37.97 & 19.08 & 3.82 & 0.09 & 0.35 & 0.13 & 5.50 & 4.60 \\
\hline B2 & $60-90$ & 43.44 & 15.71 & 2.48 & 3.12 & 0.22 & 0.02 & 9.40 & 6.40 \\
\hline B3 & $90-120$ & 40.80 & 12.96 & 2.10 & 1.19 & 0.24 & 0.04 & 7.70 & 7.60 \\
\hline
\end{tabular}

The results of other chemical properties of the original area i.e., exchange acidity $(\mathrm{Al}$ and $\mathrm{H})$, exchangeable bases $(\mathrm{Ca}, \mathrm{Mg}$, $\mathrm{K}, \mathrm{Na}$ ), Available $\mathrm{P}$ and $\mathrm{Al}$ saturations are presented in Table 3.

From Table 2 and 3, we can see that the available $\mathrm{P}$ are high, the amount of exchangeable bases at the exchange complex is associated with base saturation. If high content of exchange acidity, the low content of exchangeable bases, and Al saturation will high. Al saturation is also connected with amount of $\mathrm{Al}$ cation. It indicates that if Al saturation is high, then a lot of amount of $\mathrm{Al}$ cation at the exchange complex or base saturation is low. 
According to Prasetyo et al (2001), high $\mathrm{Al}$ saturation affects $\mathrm{Al}$ toxicity which influence problems for crop growth, and to alleviate Al toxicity by liming the soil with agricultural lime or using more organic matter.

\section{CONCLUSION}

Soils have loam texture in the topsoil while in the subsoil exhibits clay loam and sandy clay loam particle size class. Organic carbon is moderate in the top soil dan very low in the subsoil. Soil reaction is acid (4.6) throughout the horizon. Base saturation in the topsoil is moderate, and low to very low in the subsoil. Cation exchange capacity (CEC) are low to moderate. Al saturation are high, and available $\mathrm{P}$ are high to very high. The fine sand fraction is composed of quartz. Low chemical properties and high composition of resistant minerals (quartz) in the soil, indicate that soil has limited nutrient reserve or soil has low fertility.

\section{ACKNOWLEDGMENTS}

As mentioned above, the research of Chemical Properties and Mineralogical Composition of Soil in Original site at Original Site in Coal Mining, East Kalimantan. I wish to express my deep appreciation to $\mathrm{Mr}$. Fabiandis Hasibuan, the Manager of Human Resources PT. Khotai Makmur Insan Abadi, Mr. Boby, Mr. Sandri Susanto, Mr. Budi, Prof. Dr. H. Rusdiansyah , M.Si the Dean of Agriculture Faculty, Mulawarman University for their outstanding cooperation. And special thanks to all the people who helped in carrying out the field survey and the laboratory analysis, DR. Markus Anda, Mr. Tio, Mr. Odar, Mr. Arif, Mr. Edi.

\section{REFERENCES}

Allen, B. L. \& D. S. Fanning. 1983. Composition and Soil Genesis. p. 141-192. In L. P. Wilding et al. (Eds.). Pedogenesis and Soil Taxonomy. I. Concept and Interactions. Elsevier Sci. Publ. Co.,Amsterdam.

Anda, M., Mulyani, A., \& Suparto. (2012). Mineralogical Characterization and Chemical Properties of Soil as a consideration For Establishing Sustainable Soil Management Strategies. Indonesian Journal of Agricultural Science 13(2), 2012: 54-67.

Anda, M., Suparto., \& Sukarman. (2016). Characteristics of Pristine Volcanic Materials : Beneficial and Harmful effects and Their Management for Restoration of Agroecosystem. Science of The Total Environment. 543:480-492

Hardjowigeno, S. (2003). Klasifikasi Tanah dan Pedogenesis. Edisi Revisi. Akademi Pressindo. Jakarta.

Miller.B.J. (1983). Ultisol.p. 283- 325. In L.P. Wilding et al. Eds.). Pedogenesis and Soil Taxonomy. II. The Soil Orders. Elsevier Sci. Publ. Co., Amsterdam.

Ohta,S., \& Effendi,S. (1992). Ultisols of "Lowland Dipterocarp Forest" in East Kalimantan, Indonesia. Journal Soil Science and Plant Nutrition.Vol.38. 
Portela, E.,Monteiro, F.,Fonseca, M., \&Aberu, M.M. (2019). Effect of Soil Mineralogy on Potassium Fixation in Soils Developed on Different Parent Material. Geoderma 343:226-234

Pramuji \& Bustaman, M. (2009). Teknik Analisis Mineral Tanah Untuk Menduga Cadangan Sumber Hara. Buletin Teknik Pertanian. 14 (2): 80-82.

Prasetyo, B.H. (2007). Perbedaan SifatSifat Tanah Vertisol Dari Berbagai Bahan Induk. Jurnal Ilmu-Ilmu Pertanian Indonesia. 9(1) : 20-31.

Prasetyo, B. H., Suharta, N., Subagyo, H., \& Hikmatulla. (2001) Chemical and Mineralogical Properties of Ultisols of Sasamba Area, East Kalimantan. Indonesian Journal Of Agricultural Science 2(2) : 37-47.

Prasetyo, B. H., J.S. Adiningsih, K. Subagyono, \& R,D.M. Simanungkalit. 2004. Mineralogi, kimia, fisika dan biologi lahan sawah. Hlm. 36-50. Dalam F.Agus (Wd.). Lahan sawah dan Teknologi
Pengelolaannya. Pusat Penelitian

Tanah dan Agroklimat, Bogor.

Rajamuddin, U.A., Lopulisa.C., Husni, H., \& Nathan, M. (2013). Mineralogy and Micromorphology Charachteristics of Vertisol Lying on Limestone Parent Rocks at Jeneponto District of South Sulawesi Province, Indonesia. International Journal of Agricultural Systems (IJAS). Volume 1 issue 2.

Sanchez, A.S., Cerdan, M., Jorda,J.D., Amat, B., \& Cortina,J. 2019. Characterization of Soil mineralogy by FTIR; application to the analysis of mineralogical changes in soils affected by vegetation patches. Article In Plant and Soil. https://rdcu.be/busmB.

Wilding, L.P.,Smeck, N.E., \&Drees, L.R. 1977. Silica In Soils: Quartz, Cristobalite, Tridymite and Opal.p. 471-542. In. J.B. Dixon (ed.). Minerals in Soil Environments.Soil Science Society of America Madison, Wisconsin USA. 